\title{
Schematy poznawcze wśród kobiet z grupy Tzotzil w rejonie Los Altos de Chiapas w Meksyku
}

\author{
Natalia ToŁsTy
}

\begin{abstract}
Streszczenie
Schematy poznawcze organizują interpretację doświadczeń każdej jednostki. Nowa zdobyta wiedza jest filtrowana przy pomocy tych struktur myślowych, kształtowanych w dużym stopniu przez otoczenie. W związku z tym mogą być one warunkowane w jakimś stopniu przez kulturę. Artykuł zawiera analizę trzech schematów poznawczych przedstawicielek Majów Tzotzil z terenów Los Altos de Chiapas w Meksyku: tradycyjnego ortodoksyjnego, tradycyjnego nieortodoksyjnego oraz antytradycyjnego. Równocześnie poddaje interpretacji wspomniane konstrukcje, uwzględniając specyfikę kulturową mieszkanek tego terenu.
\end{abstract}

Słowa kluczowe: schematy poznawcze, kobiety, Tzotzil, Meksyk

Natalia To£STY jest doktorantką w Katedrze Porównawczych Studiów Cywilizacji na Wydziale Filozoficznym Uniwersytetu Jagiellońskiego. Jej zainteresowania naukowe skupiają się m.in. wokół prekolumbijskiej oraz współczesnej kultury Meksyku i Gwatemali. Efektem licznych wypraw badawczych było przygotowanie pracy magisterskiej na temat schematów poznawczych kobiet z grupy Tztotzil, a obecne badania dotyczą curandersimo, czyli meksykańskiej medycyny tradycyjnej. E-MAIL: natalia.tolsty@uj.edu.pl 
Indywidualne rozumienie świata przez każdego człowieka jest determinowane przez wiele elementów, takich jak, m.in. sposób wychowania i wartości przekazane przez rodzinę, dostęp do wiedzy na późniejszych etapach po okresie socjalizacji, czy nawet miejsce zamieszkania. Nowe informacje są automatycznie porządkowane wraz z już posiadanymi, symultanicznie tworząc schematy, które mają skrócić proces przyswajania wiedzy. Niniejszy artykuł analizuje możliwe schematy poznawcze kobiet z grupy Majów Tzotzil, zamieszkujących wyżynny rejon Los Altos de Chiapas w Meksyku, oraz korelację między tymi schematami a budowaną tożsamością tamtejszych kobiet.

Tekst opiera się na wynikach wyjazdu badawczego, który odbył się w 2016 roku i powstał na podstawie pracy magisterskiej dotyczącej tego samego tematu. Badania prowadzono w języku hiszpańskim z przedstawicielami Majów z grupy Tzotzil, a sam artykuł prezentuje fragment wywiadu $\mathrm{z}$ jedną z moich respondentek. Jej imię zostało zmienione na potrzeby zachowania anonimowości. Najważniejsze opracowania na temat kultury tej konkretnej grupy Majów można znaleźć u takich autorów, jak Evon Z. Vogt (Vogt 1976, 1990, 1994), czy jego uczeń, Garry H. Gossen (Gossen 1984, 1999), a klasyczne pozycje tych naukowców niewątpliwie wpłynęły na moje własne badania. Wspomniani autorzy skupili się na ogólnym i całościowym opisie społeczności, natomiast ja przeanalizowałam zebrany materiał pod kątem schematów poznawczych, stosując metodę częściowo ustrukturyzowanego wywiadu pogłębionego. Teren wybrałam ze względu na dominację autochtonów wśród miejscowej populacji, co wpływa na kultywowane tradycje i powtarzane schematy (Tołsty 2019).

\section{Schematy poznawcze - informacje kontekstowe}

Jak już zostało wcześniej zasygnalizowane, schematy poznawcze to kategoria pozwalająca usystematyzować jednostce wiedzę na temat otaczającej ją rzeczywistości. Prowadzi to do kategoryzowania poszczególnych fenomenów, podzielających te same cechy, do grup w ramach jednego wariantu. W ten sposób przedstawiciel określonej kategorii powinien posiadać sprecyzowany zestaw właściwości, które ułatwiają modelowanie zachowania jednostki wobec reprezentanta danego schematu. Nie chodzi tu jedynie o stereotypy związane z członkami określonych grup, ale również o wyobrażenia na temat własnego postępowania w grupie. Ocena odbywa się na dwóch poziomach: albo cechy jednego przedstawiciela rzutują na całą kategorię, albo 
odwrotnie, cechy odnoszące się do całej kategorii są przypisywane danemu reprezentantowi (Lee 1994, 251).

Za schematy uznaje się również wzorce myślenia, zachowania oraz presupozycje, które przyczyniają się do organizacji nowo zdobytej wiedzy. Dzieje się tak, ponieważ o wiele łatwiej zauważyć oraz zapamiętać fakty i zdarzenia wpisujące się w znany nam już schemat. Stworzenie nowego wymaga wzmożonego wysiłku poznawczego, a przy natłoku danych i prędkości przetwarzanych komunikatów wszelkie zbędne akcje muszą być pomijane. Oczywiście w razie zaistniałej potrzeby nowe schematy również są konstruowane. Przykładami takich schematów są m.in.: role społeczne, archetypy, stereotypy i światopogląd. Schematy mogą w pewnym sensie również utrudniać przyswajanie nowej wiedzy, jeśli są mocno zakorzenione w świadomości jednostki - tak działają m.in. stereotypy, niepoddawane weryfikacji (Bartlett 1933, 187-198). Na podstawie rozmów z respondentami oraz przeglądu literatury podmiotu rozpoznałam następujące skrypty życia kobiet w społeczności Tzotzil:

a) tradycyjny ortodoksyjny - w tym schemacie kobieta jest posłuszna męskim krewnym w swojej rodzinie: najpierw ojcu, a potem mężowi, stawia interes rodziny ponad swoimi własnymi ambicjami, do jej codziennych zadań należy przede wszystkim opieka nad rodziną i domem, pracuje jedynie $\mathrm{w}$ domu lub na polu należącym do rodziny, nie kwestionuje otwarcie decyzji męża, jest katoliczką w rozumieniu katolicyzmu meksykańskiego, wypełnia rytuały związane z kultem, kończy swoją edukację zaraz po wyjściu za mąż, przekazuje kolejnym pokoleniom podobną konfigurację zadań i prac domowych, ściśle związanych z podziałem płci;

b) tradycyjny nieortodoksyjny - w jakimś stopniu może pokrywać się z powyższym schematem i podzielać niektóre z jego cech, ale jedną z głównych różnic jest zazwyczaj kontynuowanie nauki po wyjściu za mąż lub późniejsze dokształcanie się kobiety, kolejne to: jej samorealizacja poprzez pracę zarobkową poza miejscem zamieszkania, przy jednoczesnej aprobacie męża, zmiana wyznania lub kwestionowanie niektórych postaw mężczyzny, np. alkoholizmu rytualnego, kobieta nadal może bronić tradycji i zwyczajów;

c) antytradycyjny - ten schemat uaktywnił się głównie pod wpływem działań Zapatystowskiej Armii Wyzwolenia Narodowego oraz Zapatystowskiego Rewolucyjnego Prawa Kobiet; kobieta żyjąca według tego schematu dąży do równouprawnienia i jest gotowa zakwestionować lub przeciwstawić się tradycyjnemu postępowaniu, chce decydować o sobie i swoich dzieciach, 
może ubiegać się o kierownicze stanowiska oraz traktowanie na równi z mężczyznami, dąży do niezależności.

Oczywiście powyższy opis nie zawiera w sobie wszystkich możliwych cech, a te wymienione w poszczególnych podpunktach nie są sztywne, konkretne jednostki zaś będą reprezentowały indywidualny zestaw atrybutów, właściwy tylko dla niej. Nie należy traktować zaprezentowanych modeli jako monolitycznego tworu, który nie jest podatny na fluktuację i migrację reprezentantek poszczególnych zespołów, mogących na każdym etapie swojego życia zmienić skrypt.

\section{Rozumienie miejsca kobiety w społeczności Tzotzil i jej schematy poznawcze}

\subsection{Tradycyjny schemat ortodoksyjny}

Christine Eber w książce The fourney of a Tzotzil - Maya Woman of Chiapas, Mexico. Pass Well over the Earth, przytacza zalecenia odnośnie tego, jak być „prawdziwą kobietą” (tzotz. batz'i antz) oraz „prawdziwym mężczyzną” (tzotz. batz’i viniketik). „Prawdziwa kobieta” karmi ojca, braci, męża, w razie potrzeby pomaga w polu, dba o ubrania dla swojej rodziny, musi pamiętać, żeby w domu zawsze była woda, a jej główną cechą jest pracowitość, nie powinna podważać opinii swoich męskich krewnych, powinna trzymać się blisko domu oraz nie może rozmawiać z nieznajomymi. „Prawdziwy mężczyzna” z kolei ma uzupełniać swoją żonę, pomagać jej w domu poprzez pracę w polu, ale może także mielić kukurydzę, przynosić drewno, karmić zwierzęta, zbierać owoce i dbać o dzieci. Małżonkowie nie powinni podnosić na siebie głosu i kłócić się, bo, według lokalnych wierzeń, brak równowagi w rodzinie może prowadzić do chorób czy śmierci. Zarówno kobieta, jak i mężczyzna, w ciągu życia mają dążyć do ideału tak rozumianej „prawdziwości”, żeby „sprawić, by przybyła ich dusza” (tzotz. ch'ulelalvulesal), z racji tego, że nie znajduje się ona w człowieku w momencie jego narodzin, a uzyskuje się ją dopiero poprzez dobre postępowanie, wykonywanie obowiązków wobec rodziny i społeczności oraz traktowanie innych z szacunkiem (Eber 2011, 19-21).

Skoro w społeczności Majów Tzotzil istnieją takie instrukcje odnośnie postępowania poszczególnych płci, warto było sprecyzować rolę kobiety w rodzinie, ustalić zadania, które musi wypełnić w obrębie gospodarstwa 
domowego oraz zweryfikować aplikację kulturowych wytycznych w praktyce. Chociaż w zebranych przeze mnie wywiadach kategoria ch'ulelal vulesal nie pojawia się wprost, opis zajęć kobiecych pokrywał się z informacjami podanymi przez Christine Eber i Antonię. Zajęcia kobiece skupiają się przede wszystkim wokół domu i podstawowymi obowiązkami są prace związane z prowadzeniem gospodarstwa: od porządków, przez gotowanie, po przynoszenie drewna. Kobieta musi odpowiednio wcześnie wstać, aby sprostać swoim zadaniom. Już samo przygotowanie podstawowego elementu każdego meksykańskiego posiłku - tortilli, czyli kukurydzianego placka - to czasochłonny proces, jeśli z jakiegoś powodu należy wykonać go ręcznie, bo nie ma dostępu do prądu. W jednej z wypowiedzi Elena (E) odnosi się do prac wykonywanych przez jej matkę:

E: Przede wszystkim pracuje $\mathrm{w}$ domu - zamiata, sprząta, prasuje, pierze, przyrządza posiłki, tortille, przynosi drewno. Dawniej - nosiła wodę. Dawniej, dawniej, dawniej, gdy nie było młyna i światła, mieliła kukurydzę na metate. Mama mi opowiadała, że cierpiała przez przygotowanie tortilli, bo mieliła $\mathrm{w}$ metate. $\mathrm{W}$ ten sposób można zrobić tortillę. To trudne. Mama mi mówiła, że nauczyła się tego, będąc dzieckiem. [...] Sądzę, że wstawała o trzeciej nad ranem, żeby zrobić tortillę - bardzo wcześnie. Żeby potem... no cóż, życie mojej mamy - żeby potem o szóstej lub wcześniej przynieść drewno. Przychodziła z drewnem i potem szła na pastwisko. Jej rodzina miała przede wszystkim dużo bydła, dlatego zawsze wychodziła na pastwiska. Wieczorem tak samo - przygotowywała nixtamal, a jeśli nie, szła do pracy w polu. [...] Życie kobiety wcześniej było trudne. [...] Jak to mówi moja mama - jeśli kobieta nic nie chce robić, jest leniwa - ponieważ na przykład mamy młynek na prąd, wodę [...]. Gdy wstaje się rano - najwcześniej o szóstej rano. To nasza godzina, to godzina Boga. W lecie o piątej. I już! Zmieli się trochę - tyle, żeby zjeść na śniadanie. Nasze życie teraz - czy moje życie w tym momencie jest inne niż to, które miała moja mama. Jeśli wstanę, przynoszę drewno do domu. Jeśli nie, mielę nixtamal, rozpalam ogień i potem szybciutko zaczynam przygotowywać tortille. [...] To, czym się zajmuję, to rękodzielnictwo wyszywanie. Cztery, pięć godzin.

W powyższej wypowiedzi Elena porównuje siebie ze swoją matką. Jest to o tyle cenna wiedza, że pozwala uchwycić postrzegane przez nią zmiany, które następowały w czasie w związku z poprawą warunków bytowych. W tym przypadku chodzi o doprowadzenie prądu oraz wody do domu, bo gdy jej matka była młodsza, ze względu na brak tych udogodnień musiała 
wstawać o godzinie trzeciej nad ranem, natomiast moja rozmówczyni wstaje o szóstej - już sama pora pobudki pokazuje, jak zmieniło się życie obu kobiet w jej własnej ocenie. Warto w tym miejscu wspomnieć, że respondentka Eber, Antonia oraz moja rozmówczyni borykały się z podobnymi problemami. Rodzina Antonii aż do końcówki lat osiemdziesiątych żyła bez dostępu do prądu, mimo że zapora hydroelektryczna w Chiapas zapewniała wtedy ponad 50\% energii całego Meksyku (Eber 2011, XXI).

W przytoczonym cytacie wspomina się głównie o przygotowaniu tortilli, jako podstawowego dodatku do posiłku. Cały proces wymagał wcześniej sporego nakładu czasu i siły, przez co bardzo obciążał stawy. Wspomniany nixtamal to rodzaj masy kukurydzianej, którego wielogodzinne przygotowanie polega na oddzieleniu łupin od ziaren, a następnie wielokrotnym podgrzewaniu ich w wodzie z limonką, odsączaniu i mieleniu (Hellin, Keleman 2010, 432). Kukurydzę mielono przy pomocy mano (rozcieracza, dosł. „ręki”) i metate (żaren), które w ogóle były pierwszym zestawem narzędzi w Mezoameryce, służącym do tej czynności (Źrałka, Olko 2008, 52). Uprzednio namoczone ziarna kukurydzy należy umieścić między kamiennym rozcieraczem w kształcie walca, a lekko zagłębionymi żarnami, następnie obracając narzędzie, rozdrobnić je (Adams 1993, 332). Po dodaniu wody do przygotowanej mąki wyrabia się ciasto, a następnie rozklepuje je na kształt cienkich, okrągłych, płaskich placków, tortilli, które z kolei wypieka się na comal, swego rodzaju patelni - blaszce. Niektóre wiejskie gospodynie meksykańskie preferują przygotowywanie tortilli na comal rozgrzanym na palenisku, a nie na piecyku gazowym, by w ten sposób kukurydziane placki wypiekły się równo i nie stwardniały, ale dzięki specjalnej prasce, zwanej tortillador, tortille przygotowuje się dużo szybciej lub korzysta się ze stoisk, gdzie można je bardzo tanio kupić. Dawniej kobiety musiały poświęcić nawet sześć godzin dziennie na odpowiednie spreparowanie kukurydzy (Hayner 1942, 494).

Jak wynika z relacji Eleny, oprócz prac wykonywanych w domu, kobieta szła również na pastwisko lub do pracy w polu. Współcześnie również ma podwójny zestaw obowiązków: stricte domowe oraz służbowe, związane z pracą zarobkową, przy czym kluczową różnicę w kobiecym życiu odegrało miejsce pracy poza domem. Na tę zmianę można spojrzeć w dwojaki sposób: po pierwsze, trzeba wziąc pod uwagę przekonania, a po drugie sferę ekonomiczną. Jeśli chodzi o kwestię przekonań, to w przypadku pracy w polu, kobieta nadal pozostaje w schemacie tradycyjnym i nie jest wystawiona na bodźce, które mogą wpłynąć na modyfikację tego schematu - takim bodźcem 
będzie inna kobieta, żyjąca wbrew tradycji, czy dostęp do mediów. Dobrze jest też zaznaczyć, że dostęp do internetu i innych mediów nie jest tak powszechny w regionach wiejskich, jak w obrębie obszaru miejskiego.

W przypadku sfery ekonomicznej, kobieta pracująca poza swoim gospodarstwem domowym dostaje pensję i dzięki temu może być bardziej niezależna oraz odważna w swoich działaniach. Podczas badań prowadziłam także wywiady z nauczycielkami. Były to kobiety po rozwodzie i już w kolejnym związku. Bardzo podkreślały fakt posiadania własnych pieniędzy, jako czynnik mający korzystny wpływ na możliwość decydowania o samych sobie, a co za tym idzie na poczucie samorealizacji.

Kolejnym elementem pojawiającym się w powyższej wypowiedzi jest także przydzielanie dzieciom konkretnych obowiązków już od najmłodszych lat. Respondentka wspomina, że jej matka nauczyła się przygotowywać tortille, będąc dzieckiem. Nauczanie konkretnych umiejętności jest wiedzą przekazywaną z pokolenia na pokolenie i stanowi element procesu socjalizacji: matka przyucza córkę do pracy, który sama wykonuje, i stara się przekazać jej swoje umiejętności, chociaż nie oznacza to, że córka musi wykonywać ten sam zawód, co matka. Niemniej, wraz z przekazywanymi umiejętnościami, automatycznie powielane są schematy realizowane przez kolejne generacje kobiet.

\subsection{Tradycyjny schemat nieortodoksyjny}

Powyżej wspomniałam o nauczycielkach, które przez niezależność finansową nie wpisywały się w ortodoksyjny schemat tradycyjny, ale to, że funkcjonowały w jakimś stopniu poza tradycją, nie oznacza kompletnego zerwania więzi ze zwyczajami. Warstwa ekonomiczna wydaje się niekiedy decydująca $\mathrm{w}$ dostępności konkretnego schematu, zatem kolejnym poruszonym zagadnieniem był podział pracy w rodzinie.

N: I kto pracuje więcej w rodzinie, tak ogólnie? Kobiety, czy mężczyźni, czy po równo?

E: [... cisza... ] To zależy od rodziny. Mogą pracować oboje, albo kobieta może nie pracować i tylko mężczyzna pracuje. Bo są mężczyźni, którzy powiedzą „nie, [od kiedy będziesz] żoną, nie będziesz pracować. Utrzymam cię, dam ci wszystko, co będziesz chciała”. Są też mężczyźni [którzy powiedzą] „jesteśmy razem, pracujemy razem”. Tak to się różni w rodzinach. To zależy od rodziny, jak się przystosuje. 
N: I co Pani sądzi - dla kobiety lepsza jest praca tylko w domu, czy w domu i jakimś innym miejscu, np. w sklepie?

E: $\mathrm{Z}$ mojego punktu widzenia - praca w innym miejscu. Bo poznajesz ludzi, rozmawiasz z ludźmi, możesz się rozerwać. [...]

Elena wspomina tutaj o dwóch możliwych rozwiązaniach: kobieta albo pracuje poza domem, albo nie jest czynna zawodowo i tym samym zależy finansowo od swojego męża. Może być zachęcana do pozostania w domu poprzez obietnicę życia w dostatku, bo ciągła obecność kobiety w domu zdecydowanie ułatwia podtrzymanie tradycyjnego schematu. Moja respondentka podaje również przykład rodzin, w których oboje małżonkowie pracują w układzie partnerskim, co skutkuje częściowym wyjściem poza tenże schemat, ale nie wiąże się z całkowitą rezygnacją z niego w innych sferach życia, $\mathrm{np}$. w przestrzeganiu zwyczajów kultowych. Ten wątek pojawia się także w innej wypowiedzi.

N: I Pani sądzi, że jest tak samo w innych rodzinach w Zinacantán, tak, jak w Pani rodzinie, gdzie kobiety mogą iść do szkoły, mogą zdecydować, czy chcą, czy nie mieć męża?

E: Myślę, że tak. [...] Prawie ten sam sposób życia. To samo zajęcie rękodziełem lub haftem lub czasami poświęcają się handlowi [...]. Mam znajomą, która właśnie poświęciła się sprzedaży warzyw. Jej życie jest inne [...].

Schemat rodziny Eleny pozostaje tradycyjny, ale nie jest ortodoksyjny, bo kobiety mogą się kształcić i dokonywać wyborów, co wiąże się również z pracą. Według niej w innych rodzinach z tej samej miejscowości obowiązują reguły postępowania podobne do jej własnych - tak samo jak Elena, kobiety zajmują się tkaniem, pozostałe sprzedażą warzyw lub innych towarów. Bodziec zewnętrzny, jakim jest konieczność utrzymania rodziny, obliguje do zmiany schematu. Można się zastanowić, jak praca zarobkowa poza domem wpłynie na status kobiety i jej prawa.

N: I kobiety mają te same prawa, co mężczyźni?

E: Nie, bo tak, jak Ci powiedziałam, kobiety zawsze muszą być w domu. Tak, może wyjść z domu, ale jeśli [mąż] powie „nie”, nie może wyjść i nie może pracować. Dla większego wyjaśnienia - nie, bo mężczyźni są zazdrośni. Bo gdy wyjdzie, spotka się z innym mężczyzną i odejdzie z nim. Były takie przypadki - kobieta miała męża i odeszła do innego. Zostawiła męża. Albo mężczyzna - miał żonę i odszedł do innej. 
Zarówno powyższy fragment, jak i wcześniejszy, pokazują generalną dominację mężczyzn w rodzinie. Kobieta musi najpierw otrzymać pozwolenie od męża, aby podjąć pracę, gdyż staje się bardziej autonomiczna w momencie posiadania własnych środków finansowych, a jej niezależność może budzić zazdrość partnera. Następnie, według słów mojej respondentki, może spotkać innego mężczyznę i ewentualnie odejść do niego - takie zachowanie przeczy schematowi, dlatego z perspektywy mężczyzny, mającego dodatkowo wyższą pozycję, lepiej zapobiegać i zatrzymać żonę w domu, gdzie można mieć nad nią kontrolę.

Warto zwrócić również uwagę na ostatnie słowa Eleny w tym fragmencie - „...Albo mężczyzna - miał żonę i odszedł do innej” - mimo że istnieje realne niebezpieczeństwo zdrady także ze strony mężczyzny, nie jest on obłożony podobną sankcją, czyli koniecznością pozostania w domu, co więcej, w Meksyku nadal występuje pewna forma poligynii, która nie jest uzależniona od statusu materialnego mężczyzny. Chociaż poligamia jest w Meksyku nielegalna, zjawisko to uzyskało swój własny termin - casa chica, czyli „mały domek", utrzymywany przez mężczyznę i zamieszkiwany przez jego drugą lub kolejną partnerkę oraz ich dzieci. Według artykułu 279 kodeksu prawa karnego, osoba będąca w związku bigamicznym może zostać skazana na karę pozbawienia wolności do pięciu lat (Código Penal Federal, Articulo 279). Mimo to mężczyźni wiążą się z innymi kobietami, nadal pozostając w legalnym związku małżeńskim z poprzednią żoną.

Wprawdzie badacze tematu, tacy jak Matthew C. Gutmann, Dolly Velasco, czy Carla Fine używają sformułowania „poligamia” dla opisu tego fenomenu (Gutmann 2007; Velasco, Fine 1972), jednak tutaj bardziej adekwatnym terminem będzie „poliamoria”, z tego powodu, że poligamia zakłada sformalizowanie wszystkich stosunków między partnerami, co, jak już zostało zauważone, w Meksyku jest nielegalne. Natomiast poliamoria polega na równoczesnym posiadaniu wielu romantycznych związków, ale nie wymaga ich legalizacji (Tweedy 2011). Gutmann podaje przypadek respondenta, który miał równocześnie trzy partnerki, ale jedynie pierwsza była jego legalną żoną, z którą żył w separacji, a kolejne dwie dodatkowymi towarzyszkami, co pozostawało legalne w świetle prawa. Badacz uważa również, że casa chica określa także drugie i każde kolejne małżeństwo, co sprowadza się do monogamii seryjnej (Gutmann 2007, 138-139). Często poszczególne kobiety wiedzą o sobie, nie muszą się różnić między sobą i mogą mieć bardzo wiele wspólnego, jednak zazwyczaj, ze względu na dzieci oraz zabezpieczenie 
finansowe, nie widzą innej możliwości, jak pozostanie w takim układzie, natomiast dla mężczyzny jest to powód do dumy, bo oznacza to, że jest w stanie utrzymać przynajmniej dwie rodziny (Velasco, Fine 1972, 2-3). Z kolei Gossen w Telling Maya Tales. Tzotzil Identities in Modern Mexico opisuje między innymi swoje doświadczenia, gdy po raz pierwszy wprowadza się do indiańskiego domu szamana w Chamula. Wyprowadza się z niego po dwóch dniach, bo dwie żony gospodarza nie mogły zgodzić się co do tego, która ma otrzymywać zapłatę za nocleg oraz wyżywienie od badacza. Problem wyniknął z tego, że dom był własnością jednej, a zapasy kukurydzy drugiej (Gossen 1998, 11).

Nie każda kobieta zgadza się na układ poliamoryczny, dlatego jedynym rozwiązaniem, jakie jej pozostaje jest rozwód, ale oczywiście istnieją też inne niż poliamoria powody rozpadu małżeństw. Instituto Nacional de Estadísticas y Geografía wśród możliwych przyczyn podaje m.in.: za porozumieniem stron, niewierność, posiadanie nieślubnego dziecka, propozycja prostytucji, przemoc, złe traktowanie dzieci, impotencję, opuszczenie domu przez jednego z partnerów itd., ale jednak większość małżeństw rozwodzi się za porozumieniem stron. W 2016 roku stan Chiapas znajdował się na 18. miejscu, spośród wszystkich stanów, co do liczebności rozwodów - w okresie od 2006 do 2016 roku zarejestrowano ich 22 702, przy czym w 2006 roku liczba odnotowanych rozwodów wynosiła 1509, a 10 lat wcześniej tylko $820 \mathrm{w}$ całym stanie (Instituto Nacional de Estadisticas y Geografía - Conjunto de Datos: Divorcios).

Wzrost liczby rozwodów to oznaka zmian percepcji społecznej odnośnie związków, a Elena wydaje się wpisywać w ten nurt ogólnej niechęci, przeświadczona o przykrych konsekwencjach małżeństwa. Moja respondentka kojarzyła ideę małżeństwa z dużą odpowiedzialnością za siebie, męża i dzieci, a mając świadomość wszystkich trudności, które mogą być związane z wychowywaniem, uważała, że w tym momencie życia taka rola nie jest dla niej. Nie oznacza to, że świadomie zrezygnowała ze związku, ponieważ wciąż pozostawała otwarta na nowe znajomości, ale pogodziła się ze swoim losem. Ponadto, jako jedno z pojawiających się skojarzeń, pojawiało się złe traktowanie. Elena obarczała w dużym stopniu za problemy rodzinne alkohol, gdyż, w jej przekonaniu, brak umiarkowania w piciu, prowadzi do przemocy. Kobiety często próbują z tego właśnie powodu przekonać swoich mężów do konwersji na nieakceptujący spożywania alkoholu protestantyzm, ponieważ w trakcie pełnienia tradycyjnych obowiązków rytualno-politycznych, 
zwanych cargos, panuje społeczne przyzwolenie na rytualne upijanie się. Obok niezależności finansowej oraz rozwodu, konwersja na protestantyzm to następny element wychodzący poza schemat ortodoksyjny.

Przestrzeganie konkretnego zestawu reguł, jak alkoholizm rytualny podczas świąt, wpisuje się w ogólny schemat posłuszeństwa poszczególnych członków wobec reszty społeczności, co przekłada się również na niższy poziom - posłuszeństwo wobec rodziny. W kraju, gdzie bardzo powszechne jest machismo, wynikające z patriarchatu, patrylokalizm to kolejna składowa schematu tradycyjnego. Gdy kobieta wchodzi w nowe środowisko, jakim jest dla niej dom rodziców męża, musi dostosować się do częściowo nowych reguł, panujących w rodzinie małżonka. Jeśli kobieta podziela bardzo podobny schemat, co mężczyzna, to przejście z rodzinnego do nowego domu będzie łatwiejsze, natomiast jeśli jej schemat różni się w znaczącym stopniu, będzie musiała go zmienić na rzecz schematu męża. Oczywiście to, kto mieszka z rodzicami, zależy od liczebności rodziny, która zmieniła się na przestrzeni czasu. Zmiana liczby dzieci nastąpiła z kilku powodów - jednym z nich jest większa świadomość planowania rodziny, kolejny to poprawa warunków bytowych, co miało duży wpływ na dożywalność dzieci. Następnym powodem modyfikacji sposobu myślenia są efekty działań ruchu Zapatystowskiej Armii Wyzwolenia Narodowego (hiszp. Ejército Zapatista de Liberación Nacional, EZLN) w latach dziewięćdziesiątych XX wieku oraz ich Rewolucyjnego Prawa Kobiet. Według złożeń EZLN kobiety wreszcie mogły decydować o liczbie dzieci i chociaż nie wszystkie przystąpiły do zapatystów, doświadczyły funkcjonowania innych schematów.

\subsection{Nowy schemat antytradycyjny: wpływ działalności EZLN}

Nie ma takiej możliwości, żeby wszyscy członkowie danego społeczeństwa bez słowa sprzeciwu dostosowywali się w pełni do wszystkich reguł panujących w danej grupie. Muszą istnieć jednostki znajdujące się poza tradycyjnym schematem, aby właśnie dzięki nim pozostałe osoby znały granice dopuszczalnych zachowań, a także konsekwencje przekroczenia ich. Bardzo wiele zmian $\mathrm{w}$ całym społeczeństwie meksykańskim zaszło dzięki wystąpieniu zapatystów - jako przykład można podać zwiększenie liczby szpitali, szkół, programów edukacyjnych. Manifestacja sprzeciwu społecznego wobec polityki rządu spowodowała, że Indianie mogli liczyć na poprawę sytuacji życiowej, ale za zmianami ekonomicznymi i politycznymi musiała 
również pójść zmiana mentalności. Nie do końca postrzegana jest jako pożądana, ponieważ niektórzy członkowie społeczności nie potrafią odnaleźć się w zastanym porządku społecznym. Głównie kobiety mają problem z dostosowaniem się do nowych reguł, bo z jednej strony nadal muszą pełnić funkcje żon i matek, natomiast z drugiej chcą realizować swoje ambicje. Umożliwia im się to jedynie w bardzo ścisłym otoczeniu aktywistów i mimo wszystko nakłada podwójny zestaw obowiązków. Równocześnie kobiety, których mężowie uważają się za zapatystów, cieszą się większą swobodą i równouprawnieniem. Przykładem takiej sytuacji był mój wywiad z jedną rodziną zapatystowską, zupełnie inny od pozostałych, bo, mimo tego, że oboje małżonkowie byli obecni i znali hiszpański, to kobieta głównie rozmawiała ze mną i nie szukała potwierdzenia swojej wypowiedzi u męża, jak to miało miejsce w przypadku kobiet, które nie wchodziły w szeregi zapatystów lub nie pracowały zawodowo. To pokazuje, że organizacja zewnętrzna, jaką jest Zapatystowska Armia Wyzwolenia Narodowego, może służyć również jako grupa wsparcia dla tych jednostek, które muszą funkcjonować między dwoma różnymi środowiskami.

Zapatyści wykazali się bardzo nowatorskim podejściem do rozumienia pozycji kobiet w społeczeństwie, czemu dali wyraz w ustalonych przez siebie Zapatystowskich Rewolucyjnych Prawach Kobiet. Należy jednak zauważyć, że egzekwowanie ich wewnątrz nie-zapatystowskiej społeczność jest raczej niemożliwe. Mniej więcej $45 \%$ członków EZLN to kobiety. Od momentu wystąpienia w 1994 roku mogły poczuć, że ich problemy są równie ważne, co problemy mężczyzn. Niektóre z nich dołączyły do ruchu, aby uciec przed przemocą domową i przymusowymi małżeństwami, z kolei inne chciały poszerzyć swoje kwalifikacje o kursy oraz szkoły, działające w caracoles, zamkniętych enklawach zapatystów. Należy wyraźnie podkreślić, że zapatystki walczą o prawa wszystkich kobiet. EZLN dawało możliwości, których te dziewczyny nie widziały w swoim dotychczasowym życiu i wchodząc w struktury armii, mogły liczyć na szacunek oraz rozwój kariery. W poszczególnych caracoles, np. Oventic, można zarówno zamieszkać, jak i dojeżdżać do nich, dlatego stanowiły rodzaj alternatywy i przy okazji wspólnoty dla tych osób, które z jakichś powodów nie chcą pozostać w swoich miastach lub wsiach. Oczywiście, stwierdzenie, że w tradycyjnych społecznościach kobiety nie cieszą się szacunkiem jest bardzo dużym uproszczeniem, bo chociażby przykład funkcji kobiety w podtrzymaniu systemu cargos pokazuje, że są one bardzo istotne jako medium tradycji, którą matki przekazują swoim dzieciom. 
Zapatystki nie negują swoich zwyczajów, wręcz przeciwnie, są z nich dumne, ale domagają się odmiennego podziału ról oraz poszanowania kobiecej autonomii (Knasnabish 2010).

\section{Podsumowanie}

Schematy poznawcze to płynna konstrukcja, kształtowana przez całe życie, poddawana aktualizacji, w zależności od warunków, ułatwiając jednostce systematyzowanie wiedzy na temat świata. Takimi schematami są stereotypy, przyjmowane role społeczne, czy archetypy. Powyżej zostały wydzielone trzy typy takich schematów, które zaobserwowano wśród kobiet z grupy Majów Tzotzil, zamieszkujących tereny Los Altos de Chiapas w Meksyku. Zalicza się do nich tradycyjny schemat ortodoksyjny, tradycyjny schemat nieortodoksyjny oraz schemat antytradycyjny.

Mimo zmian, które zaszły pod wpływem postępującej globalizacji oraz ogólnego rozwoju państwa, tradycyjny schemat ortodoksyjny wciąż jest realizowany wśród Indian zamieszkujących wiejskie tereny stanu Chiapas. Tutaj od każdego członka społeczności wymaga się posłuszeństwa wobec rodziny, wobec grupy, a tym samym - wobec tradycji. Jednak w sytuacji kobiet żyjących w tradycyjnych, konserwatywnych rodzinach, to warunki ekonomiczne, sposobność zarobienia większej ilości pieniędzy oraz potrzeba utrzymania rodziny legitymizują zmianę schematu. Jeśli kobieta przejmuje rolę głównego żywiciela, może podejmować decyzje. Zapewne na sytuację w rodzinie wpływa też charakter poszczególnych jej członków, a nie tylko normy kulturowe, niemniej można sprecyzować kilka okoliczności rzutujących na jakość życia współczesnych Indianek Tzotzil. Podjęcie pracy zarobkowej poza domem, zwiększenie poziomu wykształcenia, lepsza dostępność do prądu i bieżącej wody, czy rewolucja polityczna sprawiły, że kobiety doświadczają większej ilości bodźców, co może prowokować zmianę schematu. Niemniej jakakolwiek modyfikacja nie pozostaje bez konsekwencji i odejście od tradycji może powodować wykluczenie jednostki z grupy, bądź trudności w dopasowaniu się, jak to ma miejsce w przypadku kobiet wstępujących w szeregi Zapatystowskiej Armii Wyzwolenia Narodowego. W ten sposób powstaje dysonans, bo z jednej strony pojawia się obietnica równouprawnienia, a z drugiej - kobieta nadal musi przestrzegać poprzednich reguł i okazać posłuszeństwa wobec rodziny. Jednak nawet jeśli kobieta znów postanowi wrócić do poprzedniego zachowania, nie da się powrócić do poprzedniego 
skryptu. Sposób myślenia, a zatem schemat poznawczy, może być kształtowany najpierw przez najbliższe otoczenie, ale potem modyfikuje się pod wpływem różnorodności bodźców, co wpływa na jej interpretację rzeczywistości. Wcześniejsze warunki po przekształceniu skryptu nigdy więcej nie będą tak samo rozumiane.

\section{Bibliografia}

Adams, Jenny L. 1993. Toward Understanding the Technological Development of Manos and Metates. W Kiva, vol. 58, nr 3. Tylor \& Francis. Londyn. Bartlett, Frederic. 1933. Remembering: A Study in Experimental and Social Psychology. W British fournal of Educational Psychology, vol. 3, nr 2, Cambridge University Press, Londyn.

Código Penal Federal - Articulo 279. https://www.chicagomanualofstyle.org /tools_citationguide/citation-guide-2.html. Data dostępu: 06.09.2020.

Eber, Christine, Antonia. 2011. The fourney of a Tzotzil - Maya Woman of Chiapas, Mexico. Pass Well over the Earth. University of Texas Press. Texas.

Gossen, Gary H. 1984. Chamula in the World of the Sun. Time and Space in a Maya Oral Tradition. Prospect Heights, Ill. Waveland Press.

Gossen, Gary H. 1999. Telling Maya Tales. Tzotzil Identities in Modern Mexico. Routledge. New York.

Gutmann, Mathew C. 1996, 2007. The Meanings of Macho: Being a Man in Mexico City. 2nd edition. University of California Press. Los Angeles.

Hayner, Norman S. 1942. Notes on the Changing Mexican Family. In American Sociological Review, vol. 7, $\mathrm{nr}$ 4, American Sociological Association.

Hellin, Jon. Alder Keleman i Mauricio Bellon. 2010. Maize Diversity and Gender: Research from Mexico. W Gender and Development, vol. 18, nr 3. Taylor \& Francis. Londyn.

Instituto Nacional de Estadísticas y Geografía - Conjunto de Datos: Divorcios. https://www.inegi.org.mx/temas/nupcialidad/. Data dostępu: 06.09.2020.

Knasnabish, Alex. 2010. Zapatistas Rebellion from the Grassroots to the Global. Zed Books. Londyn.

Lee, Moonkyu. 1994. Category-based Versus Piecemeal Processes Underlying Evaluations of Restaurants. W Psychological Reports, vol. 74, $\mathrm{nr} 1$ (2/1994). SAGE Journals. Londyn. 
Tołsty, Natalia. 2019. Tabu edukacji kobiet $z$ grupy Majów Tzotzil $z$ rejonu Los Altos de Chiapas w Meksyku. W Magazyn antropologiczno-społecznokulturowy MASKA, nr 41/2019. AT Wydawnictwo. Kraków.

Tweedy, Ann. 2011. Polyamory as a Sexual Orientation. W University of Cincinnati Law Review, vol. 79, nr 4. Cincinnati College of Law. Cincinnati.

Velasco, Dolly. Carla Fine. 1972. The Inhabitants of Casas Chicas. W Off Our Backs. A Women's Newsjournal, vol. 2, $\mathrm{nr}$ 7. off our backs, inc. Arlington.

Vogt, Evon Zartman. 1976. Tortillas for the Gods: a Symbolic Analysis of Zinacanteco Rituals. Harvard University Press. New York.

Vogt, Evon Zartman, 1990. The Zinacantecos of Mexico : a Modern Maya Way of Life. Second Edition. Harvard University Press. New York.

Vogt, Evon Zartman. 1994. Fieldwork Among the Maya. Reflections on the Harvard Chiapas Project. University of New Mexico Press. Albuquerque.

Źrałka, Jarosław, Justyna, Olko. 2008. W krainie czerni $i$ czerwieni. Kultury prekolumbijskiej Mezoameryki. Wydawnictwo Uniwersytetu Warszawskiego. Warszawa. 


\title{
Abstract, keywords, about the author
}

\begin{abstract}
The Narrative Scripts among the Maya Tzotzil Women in the Area of Los Altos de Chiapas in Mexico

Narrative scripts organize the interpretation of each individual's experience. New gained knowledge is filer out by these structures, largely shaped by the environment. Therefore, they may be conditioned to some extent by culture. There is an analysis of three cognitive scripts of Maya Tzotzil women from Los Altos de Chiapas area in Mexico: traditional orthodox, traditional unorthodox and anti-traditional. At the same time, there is an interpretation of these constructions, taking into account the cultural specificity.
\end{abstract}

Keywords: narrative scripts, women, Tzotzil, Mexico

Natalia To£sty is a $\mathrm{PhD}$ student in the Centre for Comparative Studies of Civilisations at the Faculty of Philosophy of Jagiellonian University in Cracow, Poland. Her research interests focus on the subject of both pre-Columbian and modern culture of Mexico and Guatemala. The result of numerous field expeditions was the master thesis on the subject of narrative scripts of Tzotzil women, and current research concerns curanderismo, i.e. Mexican traditional medicine.

E-MAIL: natalia.tolsty@uj.edu.pl 